CASE REPORT

\title{
Oblong Sesamoid Bone Appearance into the Nuchal Ligament. A Case Report
}

\author{
Themistoklis Tzatzairis ${ }^{1}$, Jannis V. Papathanasiou ${ }^{2}$, Athanasios Ververidis ${ }^{1}$, loannis Kazakos ${ }^{3}$, \\ Georgios Drosos ${ }^{1}$, Konstantinos Tilkeridis' \\ 1 Department of Trauma and Orthopaedics, Democritus University of Thrace, Alexandroupolis, Greece \\ ${ }^{2}$ Department of Physical and Rehabilitation Medicine, Faculty of Medicine, Medical University of Plovdiv, Plovdiv, Bulgaria \\ ${ }^{3}$ Faculty of Medicine, Medical University of Plovdiv, Plovdiv, Bulgaria
}

\section{Correspondence:}

Themistoklis Tzatzairis, Department of Trauma and Orthopaedics, Democritus University of Thrace, Dragana, 6810 Alexandroupolis, Greece

E-mail: ttzatzai@gmail.com

Tel: +306 949453448

Received: 21 July 2016

Accepted: 25 July 2017

Published Online: 07 Sep 2017

Published: 30 March 2018

Key words: nuchal, cervical spine, sesamoid, fabella

Citation: Tzatzairis T, Papathanasiou JV, Ververidis A, Kazakos I, Drosos G, Tilkeridis K. Oblong sesamoid bone appearance into the nuchal ligament. A case report. Folia Med (Plovdiv) 2018;60(1):175-9.

doi: 10.1515/folmed-2017-0079
Radio-opaque formations behind the spinous processes of the cervical spine are really rare. They were described in 1929 for the first time. Sesamoid ossicles are found close to a bone or a joint and are usually small. Some sesamoids form part of normal human anatomy, while others are normal anatomical variants. We report a case of a 73-year-old Caucasian male who visited the outpatient clinic complaining about chronic cervical pain. An oblong sesamoid accidentally discovered during routine anteroposterior (AP) and lateral x-ray, within the nuchal ligament $(\mathrm{NL})$ at the C3-C6 spinous processes level. A cervical MRI scan was performed and the result showed 'fabella nuchae'. This type of sesamoids are rarely symptomatic, but it should be differentially diagnosed anyway. We review its morphology, the mechanical factors of the region acting throughout life and last, but not least, the differential diagnosis.

\section{CASE REPORT}

A 73-year-old Caucasian (farmer) male, presented at the outpatient department of our hospital complaining about chronic cervical pain during last 3 years. He also reported a slight tingling and numbness at his right upper limb. His past medical history was significant for systemic hypertension under medication and no history of cervical trauma. Physical examination revealed normal cervical range of motion and a mild pain on cervical extension which worsened under local pressure. Neurological examination of upper limb was normal without any motor and sensory limitations. Routine $x$-ray examination (anteroposterior and lateral views) was performed and revealed a 3-cm oblong ossicle within the nuchal ligament (NL) at the level of C3-C6 vertebral spinous processes (Figs 1a, 1b). The ossicle had smooth borders in the upper part, whereas the lower part had irregular borders. Avulsion fracture was excluded because of its prolonged shape, while the tips of the corresponding spinous processes had no defects. In addition, cervical spondylosis were noticed too, especially at the level C3-C4-C5-C6. A cervical MRI scan was performed and the result showed fabella nuchae coupled with cervical degenerative disc disease (Figs 2, 3). The initial hypothesis of sesamoid ossicle within the nuchal ligament was confirmed after the MRI result. Conservative treatment decided and the patient's symptoms resolved with physical therapy (shockwave therapy) and per os administration of nonsteroidal anti-inflammatory drugs (NSAIDs). No episode of numbness has been reported till now.

\section{DISCUSSION}

Soft tissue's ossification is not a rare condition. It's been described in many cases and allocated in many regions in human's body. However, the 


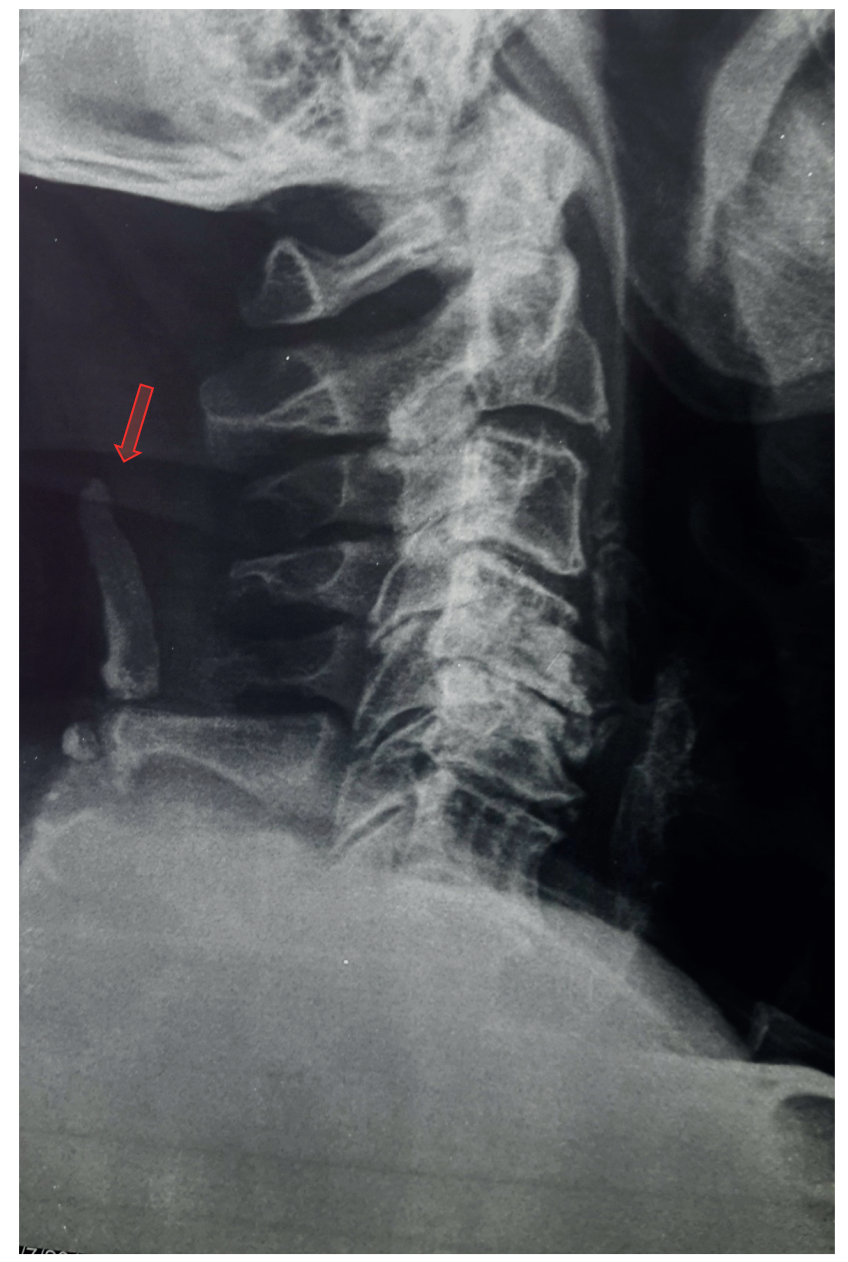

Figure 1a. Profile cervical spine $\mathrm{X}$-ray (red arrow pointing at the lesion).

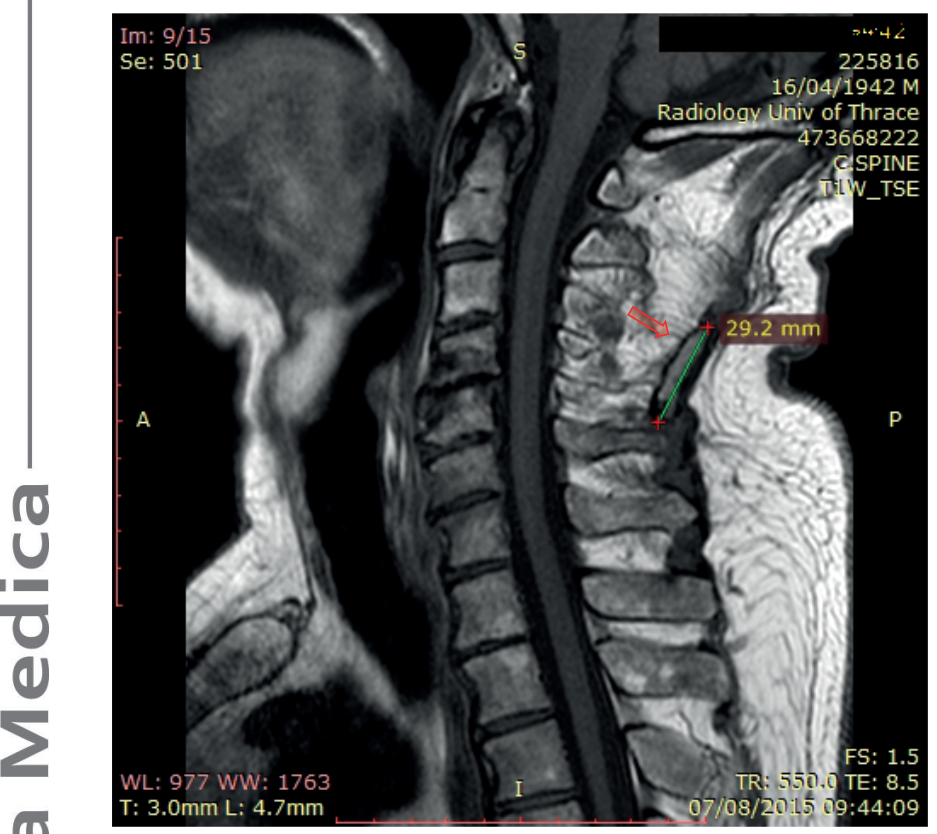

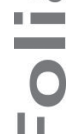

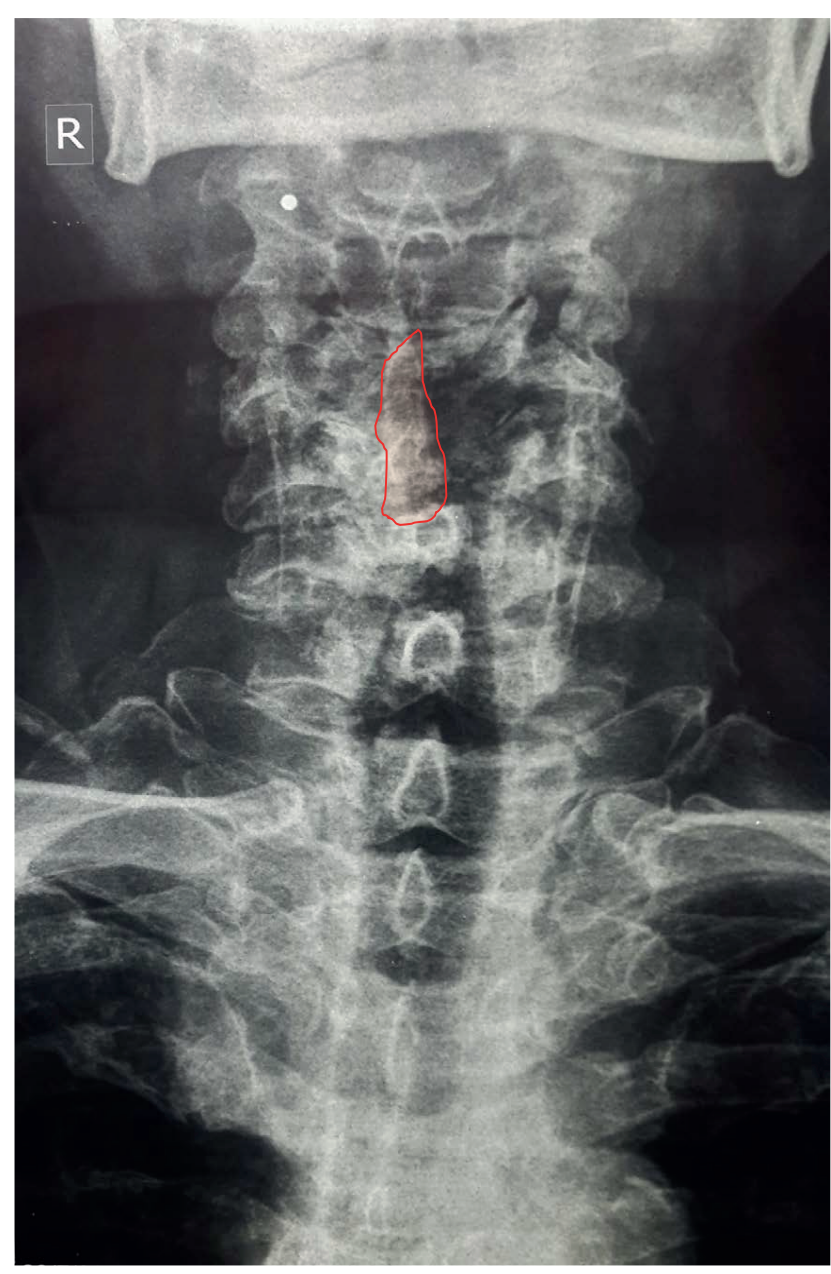

Figure 1b. Anteroposterior axial cervical spine X-ray (red line encircles the lesion).

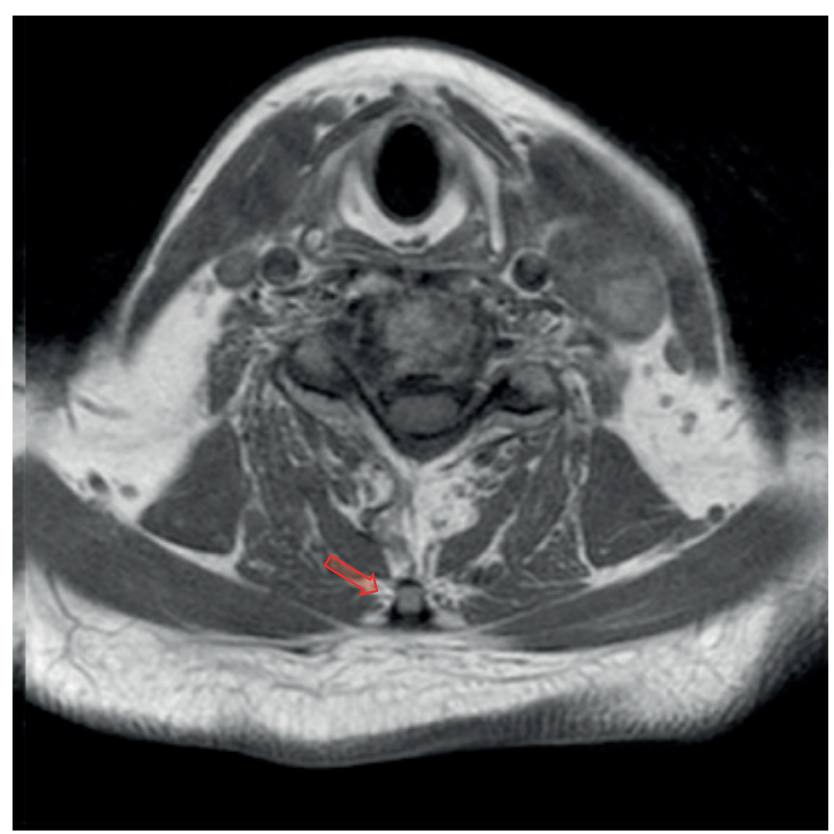

Figure 3. T1 weighted MRI (cross sectional view); (red arrow pointing at the lesion). 
existence of bone-sesamoid ossicle within the NL as a result of ossification is really uncommon and usually an adventitious discovery. ${ }^{1}$ Intensive and careful examination is mandatory to be performed in order to avoid misdiagnosis like myositis ossificans circumscripta (MOC), nuchal fibrocartilaginous pseudotumor (NFP), Clay-shoveler's fracture, neoplasms, calcinosis circumscripta and diseases with calcification deposition. ${ }^{2}$

Sesamoids are small usually rounded bones, embedded in tendons and usually related to joint surfaces. ${ }^{3,4}$ They can also arise in ligaments, and their diameter is usually just a few millimeters. Their function is to adjust the direction of the tendon and modify pressure, thereby diminishing friction. The majority of these sesamoids begin as cartilaginous nodules that undergo endochondral ossification during early to late childhood, between the ages of 3 and 12. They are present as cartilaginous nodules in the fetus, and usually in greater numbers than in the adult, but it seems that physical facts probably regulate the degree of their development. ${ }^{5}$

Nuchal ligament is the cranial continuation of the interspinous and supraspinous ligaments. The NL extends from the external occipital protuberance on the skull and median nuchal line to the spinous process of the seventh cervical vertebra in the lower part of the neck. It is positioned between the paired groups of splenius capitis, serratus posterior, rhomboideus minor and trapezius. Its structure is based on a two-layered fibroelastic septum. Nuchal ligament's function limits flexion of the head and neck and provides attachment surface for the dorsal muscles of the neck. Its significant role to lordotic alignment of the cervical spine and stabilization of the head during movement of the cervical spine has been reported. ${ }^{6}$

This type of ossification develops after the third decade of life, with its peak at the age of 50-60 years. In $75-81 \%$ of cases it is found at the level of $\mathrm{C} 4-\mathrm{C} 5$ or C5-C6. This incidence is 2-3 times greater in males than females. Cervical spondylosis disease, seems to be a predictive factor. The NL is the most posterior ligament which helps body to maintain stability of cervical spine. ${ }^{7}$ Any change in its anatomy or structure may have effect on the cervical-spinal canal diameter. It seems that this type of ossification is similar to other cervical syndromes like ossification of anterior longitudinal ligament or posterior longitudinal ligament. ${ }^{1}$ It's not fully defined if nuchal ligament ossification is a simultaneous disorder of cervical spine or a risk factor of other cervical degenerative diseases. ${ }^{2}$

Recurrent acute injury of cervical spine, and more specific in NL seems to be the most common cause of its ossification. ${ }^{8}$ MOC is a benign condition of non-neoplastic heterotopic bone formation in the muscle or soft tissue in which, solitary or multiple irregular or linear shaped dense osseous formations are developed. ${ }^{9}$ NFP is a very rare non-neoplastic lesion, probably arising through a post-traumatic metaplasia of the nuchal ligament in which a low intensity mass arises. ${ }^{10}$ Clay-shoveler's fractures are stable, isolated spinous process fractures of the lower cervical and upper thoracic vertebrae classically seen at the C6 or $\mathrm{C} 7$ level. ${ }^{11}$ Nevoid basal cell carcinoma syndrome (NBCCS), also known as Gorlin-Goltz syndrome, is an uncommon multisystemic disease with a range of developmental anomalies and predisposition to a range of neoplasms. It has been reported that spine $\mathrm{X}$-rays revealed calcification of the nuchal ligament in $18 \%$ of the general population. ${ }^{12}$ Calcinosis circumscripta presents with multiple white dermal papules, plaques or subcutaneous nodules which are found in varying distribution. It is most often seen in early stages of polymyositis, dermatomyositis, SLE and CREST syndrome but can also be seen after trauma, with connective tissue disorders, insect bites or tumours. ${ }^{13}$ Eventually, diffuse irregular nodular calcifications as a result of soft-tissue calcification, can result from many diseases, systemic or not, like gout, scleroderma, hyperparathyroidism, hypoparathyroidism, renal osteodystrophy, hypervitaminosis D, thermal injury and dermatomyositis. Additionally, primary malignant tumors of the cervical spine are really rare accounting for $0.4 \%-1 \%$ of all tumors. Only $10 \%$ of these affect the spine. However, they should be included in our differential diagnosis as neck or radicular pain is the most common initial symptom. Clinical and radiographic evaluation should be the first step in patient's evaluation and when malignancy is suspected, biopsy, oncologic/ surgical staging, specific operative techniques and auxiliary therapies should be implemented. Vigilance is required by clinicians, as spinal tumors fall into a distinct category. Their immediate diagnosis and the essential institution of treatment have an enormous impact on the patient's overall prognosis/cure. ${ }^{14,15}$ All these conditions should be widely different diagnosed from nuchal sesamoid.

The existence of these ossicles can be an incidental radiological finding. The exact pathogenesis is not known and they usually occur with chronic cervical pain. These calcifications, in most cases 
seem to be inoffensive and can be treated just with NSAID's and extracorporeal shockwave therapy (ESWT). Shockwave energy has a mechanical impact force which can destroy and clean the mucoid substance that forms following frequent microtrauma or inflammation. This substance disturbs the healing of a tendon or ligament injury. Regarding surgical excision, it's really important to mention that nuchal ligament should not be injured as it plays an important role for cervical spine stability. Moreover, its injury may affect the flexibility and muscular activities of the neck region. Therefore, surgical excision has never been proposed as treatment. ${ }^{16}$ Clinicians and radiologists should be really careful during differential diagnosis because of the severe conditions that can mimic fabella nuchae, some of them leading to death.

\section{REFERENCES}

1. Katayama H, Nanjo T, Saito M, et al. [Radiological analysis of the ossifications of the nuchal ligaments (ONL) (author's transl)]. Rinsho hoshasen. Clinical radiography. 1982;27(1):91-95.

2. Luo J, Wei X, Li JJ. [Clinical significance of nuchal ligament calcification and the discussion on biomechanics]. Zhongguo Gu Shang (China journal of orthopaedics and traumatology.) 2010;23(4):305-307.

3. Paraskevas GK, Raikos A, Martoglou S, et al. Sesamoid ossicles within the nuchal ligament: a report of two cases and review of the literature. J Radiol Case Rep 2011;5(8):22-29.

4. Yuce I, Pirimoglu B, Polat G, et al. A sesamoid ossicle of the nuchal ligament mimicking spinous avulsion fracture. Spine J 2016;16(2):e39.

5. Ogden JA, Murphy MJ, Southwick WO, et al. Radiology of postnatal skeletal development.
XIII. C1-C2 interrelationships. Skeletal radiology. 1986;15(6):433-8.

6. Kadri PA, Al-Mefty O. Anatomy of the nuchal ligament and its surgical applications. Neurosurgery Nov 2007;61(5 Suppl 2):301-4; discussion 304.

7. Takeshita K, Peterson ET, Bylski-Austrow D, et al. The nuchal ligament restrains cervical spine flexion. Spine 2004;29(18):E388-93.

8. Wang H, Zou F, Jiang J, et al. Analysis of radiography findings of ossification of nuchal ligament of cervical spine in patients with cervical spondylosis. Spine 2014;39(1):E7-E11.

9. Baudart P, Cesini J, Meyer E, et al. Myositis ossificans circumscripta. Joint Bone Spine 2016;83(1):99.

10. Nicoletti GF, Platania N, Cicero S, et al. Nuchal fibrocartilaginous pseudomotor. Case report and review of the literature. J Neurosurg Sci 2003;47(3):173-5;

11. Hakkal HG. Clay shoveler's fracture. Am Fam Physician 1973;8(1):104-6.

12. Kimonis VE, Mehta SG, Digiovanna JJ, et al. Radiological features in 82 patients with nevoid basal cell carcinoma (NBCC or Gorlin) syndrome. Genet Med 2004;6(6):495-502.

13. Olsen KM, Chew FS. Tumoral calcinosis: pearls, polemics, and alternative possibilities. Radiographics 2006;26(3):871-85.

14. Papagelopoulos PJ, Mavrogenis AF, Currier BL, et al. Primary malignant tumors of the cervical spine. Orthopedics 2004;27(10):1066-75.

15. Mavrogenis AF, Guerra G, Romantini M, et al. Tumours of the atlas and axis: a 37-year experience with diagnosis and management. La Radiologia medica 2012;117(4):616-35.

16. Lin TY, Chen JT, Chen YY, et al. The efficacy of ultrasound-guided extracorporeal shockwave therapy in patients with cervical spondylosis and nuchal ligament calcification. Kaohsiung J Med Sci 2015;31(7):337-43 


\section{Наличие удлиннённой сесамовидной кости в затылочной связке}

Фемистоклис Цацаирис ${ }^{1}$, Янис В. Папатанасиуㄹ, , Атанасиос Верверидис ${ }^{1}$, Йоанис Казакос ${ }^{3}$, Георгиос Дросос ${ }^{1}$, Константинос Тилкеридис ${ }^{1}$

${ }^{1}$ Кафедра травматологии и ортопедии, Университет Фракии им. Демокрита, Александруполис, Греция

2 Кафедра физиотерапии и реабилитационной медицины, Факультет медицины, Медицинский университет - Пловдив, Пловдив, Болгария

${ }^{3}$ Факультет медицины, Медицинский университет - Пловдив, Пловдив, Болгария

\begin{abstract}
Адрес для корреспонденции: Фемистоклис Цацаирис, Кафедра травматологии и ортопедии, Университет Фракии им. Демокрита, Александруполис, Греция

E-mail: ttzatzai@gmail.com

Tel: +306949453448
\end{abstract}

Дата получения: 21 июля 2016 Дата приемки: 25 июля 2017 Дата онлайн публикации: 07 сентября 2017

Дата публикации: 30 марта 2018

Ключевые слова: затылочный, шейный отдел позвоночника, сесамовидый, фабелла

\section{Образец цитирования:}

Tzatzairis T, Papathanasiou JV, Ververidis A, Kazakos I, Drosos G, Tilkeridis K. Oblong sesamoid bone appearance into the nuchal ligament. A case report. Folia Med (Plovdiv) 2018;60(1):175-9.

doi: 10.1515/folmed-2017-0079
Рентген-непрозрачные образования спинальных корешков в шейном отделе позвоночника действительно являются редкими и описываются с 1929 года. Сесамовидные косточки отмечаются в области кости или сустава и обычно являются исключительно мелкими. Некоторые из сесамовидных костей являются частью нормальной анатомии человека, тогда как другие являются нормальными анатомическими разновидностями. Мы сообщаем о случае 73-летнего мужчины белой рассы, который при посещении амбулатории жаловался на хроническую боль в области шеи. Случайно обнаруживается удлинённая сесамовидная кость во время рутинной передне-задней и латеральной рентгенографии, которая расположена в затылочной связке (3С) на уровне С3 С6. Был проведён магнитный резонанс шейной области, который установил „затылочную фабеллу“. Данная разновидность сесамовидных костей редко проявляет симптомы, но обязательно необходима дифференциальная диагностика. Мы проследили морфологию, механические факторы области, которые воздействуют на протяжении всей жизни и не на последнем месте по значению - дифференциальную диагностику. 